\title{
In memoriam Dr. Ângelo Machado
}

\author{
Ângelo Machado - In memoriam (1934-2020) \\ Francisco CARDOSO ${ }^{1}$
}

${ }^{1}$ Universidade Federal de Minas Gerais, Medical School, Internal Medicine Department, Neurology Service, Movement Disorders Unit, Belo Horizonte MG, Brazil.

Francisco CARDOSO (DD https:// orcid.org/0000-0003-0808-0116

Correspondence: Francisco Cardoso; E-mail:fecardosoc@gmail.com

Conflict of interest: There is no conflict of interest to declare.

Received on April 20, 2020;

Received in its final form

on April 20, 2020; Accepted on April 21, 2020.

\section{(cc) BY}

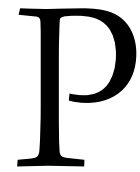

rofessor Ângelo Barbosa Monteiro Machado, MD-PhD was born in Belo Horizonte City on the 25th of May, 1934). He graduated from the Medical School of Universidade Federal de Minas Gerais (UFMG) but never practiced Medicine. Despite this fact and paradoxically, as we shall see, he exerted a profound and lasting influence over Medicine, particularly in the fields of Neurology and Neurosurgery. Immediately after graduating, he became part of the faculty at the Anatomy Department of UFMG, where received his $\mathrm{PhD}$ title in 1963. From 1965 to 1967, he was a research post-doctoral fellow at the Morphology Department of Northwestern University in Chicago, IL. Upon his return to Brazil, in partnership with his main collaborator and wife, Professor Conceição Ribeiro da Silva Machado (1936-2007), he founded the Laboratories of Electron Microscopy and Neurobiology at the Institute of Biological Sciences of Universidade Federal de Minas Gerais (Laboratórios de Microscopia Eletrônica e Neurobiologia do Instituto de Ciências Biológicas, ICB-UFMG). After retiring as a Professor at the Morphology Department in 1987, he returned to work at the same ICB-UFMG, but this time at the Laboratory of Insects Systematic of the Zoology Department (Laboratório de Sistemática de Inseto do Departamento de Zoologia). After compulsory retirement in 2004, he became Professor Emeritus at ICB-UFMG in the following year. His most significant contributions in the field of Neurobiology were to elucidate the formation of norepinephrine containing synaptic vesicles from the smooth endoplasmic reticu$\operatorname{lum}^{1}$ as well as several aspects of involvement of the autonomic nervous system in experimental models of Chaga's disease ${ }^{2}$. In the field of Entomology, his area of expertise was

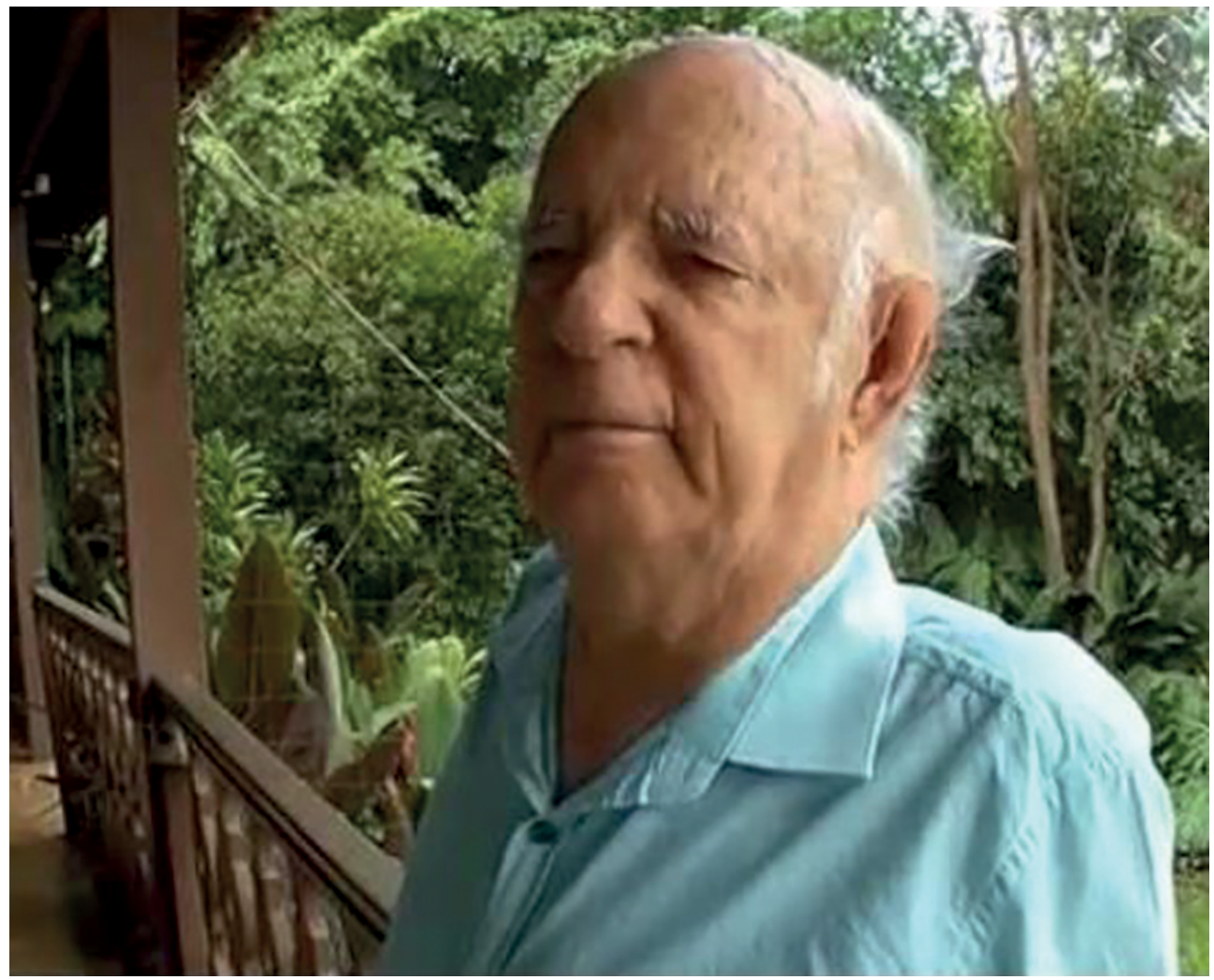

Ângelo Barbosa Monteiro Machado, MD-PhD. 
dragonflies. He described the astonishing number 98 species and 11 genres of these insects. By the way, Professor Ângelo loved dragonflies so much that the tiles marking the rim of the water of the swimming pool at his house were illustrated with drawings of dragonflies. The third intellectual activity to which he was involved was environmentalism. At an age when this was an issue that deserved at best rare footnotes, he vigorously engaged himself on the defense of the environment. Moreover, he developed a late interest in literature, writing dozens of plays and books. Most of them targeted children and teenagers. In 1993, he received the Jabuti Award for the book $O$ velho da montanha, uma aventura amazônica. The Jabuti Award is the most prestigious award in Brazilian letters, comparable to the Pulitzer Prize in the USA.

His indelible legacy for Neurology had an almost serendipitous nature. Already an assistant to Professor João Afonso Liberato Didio, MD-PhD, then Professor and Chief of Anatomy at UFMG, always tongue-in-cheek, he thought that "there was no future in dissecting". He moved to the sector of Neuroanatomy. With his remarkable didactic skills, he rendered intelligible a subject that was virtually inaccessible to Medical students. Up to that time, they were forced to study thick and hermetic foreign textbooks. The students started copying the lectures, typed them, bounded them together and created a makeshift book that circulated among them semester after semester. After that, Professor Ângelo curated the text and this is how the first edition of the textbook Functional Neuroanatomy (Neuroanatomia Funcional) gained life ${ }^{3}$. There is a fastidious overuse of the adjective seminal. Yet in this particular case it is fitting to associate this book with a reproductive function: there are very few Brazilian neurologists that have not fallen in love with the nervous system and decided to pursue a career in Neurology after reading such work.

I regret for those who did not have the privilege of meeting Professor Ângelo Machado. To be born in an aristocratic family with plenty of towering figures in Medicine (Lucas Machado), Politics (Cristiano Machado), and Literature (Maria Clara Machado and Abílio Machado) may be an easy way to have one's talent blocked. However, and fortunately, this never happened to him. Aside his intellectual prowess, he was an eccentric and deliciously funny man, warmly called "Angelim" by his peers and students. He also had many other scientific and non-scientific interests. Among these, he was endowed with an unmatched skill for foreign languages; he was a talented amateur comic actor during the Medical School and was a nocturnal flanêur in the bohemian scene of Belo Horizonte. His retirement of the latter (by the way, bitterly regretted by his fellow bohemians!) was caused by the most fateful event of his life: passion for and marriage with Professor Conceição née Ribeiro Machado, resulting not only in a highly productive scientific partnership, but also in the birth of Lúcia (neuro-pediatriacian), Flávia (intensivist), Paulo (biologist) and Eduardo (employee of the Brazilian Central Bank). Professor Ângelo Machado died on the $6^{\text {th }}$ of April 2020.

\section{References}

1. Machado AB, Machado CR, Wragg LE. Catecholamines and granular vesicles in adrenergic axons of the developing pineal body of the rat. Experientia. 1968 May;24(5):464-5. https://doi.org/10.1007/ bf02144394 acetyltransferase activity of rat tissues during Chagas' disease. Braz J Med Biol Res.1987;20(6):697-702.

3. Machado A. Neuroanatomia Funcional. Rio de Janeiro: Editora Atheneu, 1974. 